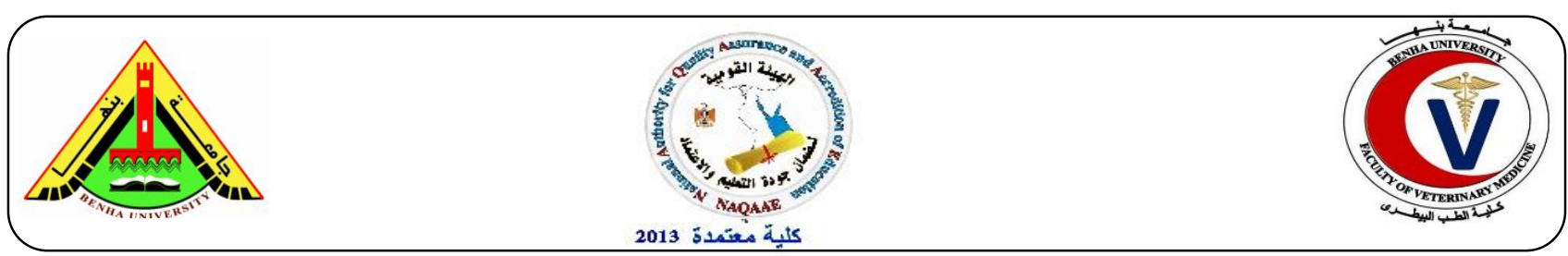

\title{
Lycopene Attenuated Nitrosodiethylamine-Induced Hepatocarcinogenesis by Modulating the Metabolic Activation and Detoxification Enzymes
}

\author{
Samy A. Hussein, Yakoot A. EL-senosi and Kamilia K. El- Hajjar \\ Department of Biochemistry, Faculty of Veterinary Medicine, Benha University
}

\section{A B S T R A C T}

Lycopene was shown to exert anti-inflammatory, antioxidant, hepatoprotective properties, and anticancer activity. This study was done to investigate the protective effects of Lycopene on diethylnitrosamine (DEN)- induced hepatocarcinogensis in rats. Forty-five male albino rats were divided into three groups. Group I (normal control group): rats administered distilled water only. Group II: rats received diethylnitrosamine (200 mg/kg b.wt/i.p), two weeks later rats received (2 $\mathrm{ml} / \mathrm{kg}$ b. wt) Carbon tetrachloride (CCl4) orally at 1:1 dilution in corn oil as a promoter of carcinogenic effect. DEN and $\mathrm{CCl} 4$ injections were repeated once again after 1 month from first DEN injection. Group III: rats received $\mathrm{DEN}+\mathrm{CCl} 4$ as in group II then treated with lycopene at a dose of $(20 \mathrm{mg} / \mathrm{kg} \mathrm{b.wt/orally)} \mathrm{dissolved} \mathrm{in} \mathrm{tween-80 \%} \mathrm{for} 6$ weeks. All animals were sacrificed after the end of experiment. DEN induced HCC showed significant increase in hepatic marker enzymes (ALT and ALP), total bilirubin and alpha fetoprotein (AFP) with marked decrease in serum albumin concentration. Also, the results of molecular analysis in liver tissue revealed significant up-regulation in TNF- $\alpha$ gene expression level. Conversely, down-regulation in tumor suppressor gene p53 and Cyp2E1 gene expression compared with control group. Treatment with lycopene to DEN induced HCC protects the liver cells from damage by regulating the biochemical parameters. Lycopene was able to mitigate liver tissue damage induced by DEN through increasing of Cyp2E1 and P53 in addition to decreasing TNF- $\alpha$ gene expression level and ameliorate all serum liver function parameters. These findings suggested, the potential efficacy of lycopene as an additional chemo preventive agent in treatment of hepatocellular carcinoma by modulating the apoptosis, anti-inflammatory and detoxification effects.

Keywords: Diethylnitrosamine, Hepatocellular carcinoma, Lycopene, apoptosis, CYP 2 E1.

(http://www.bvmi.bu.edu.eg) (BVMJ-35(2): 625-637, 2018)

\section{Introduction}

Hepatocellular carcinoma (HCC) is a malignant neoplasm of hepatocytes and constitutes more than $80 \%$ of primary malignant liver neoplasms (Satir,2007). Worldwide, liver cancer is the fifth most common malignancy and the third most common cause of cancer death (Kung et al., 2010). The major avoidable causes of cancer are smoking, dietary imbalances, chronic infections and hormonal factors which are influenced primarily by lifestyle, other causal factors in human cancer are excessive sun exposure, viruses (such as human papilloma virus and cervical cancer) and pharmaceuticals (such as phenacetin, some chemotherapy agents, diethylstilbestrol, and estrogen) (Gold et al., 2002). Many hepatocarcinogens such as aflatoxins, 
acetylaminofluorene and diethylnitrosamine have been successfully used to develop hepatocarcinogenesis in animals (Mukherjee et al., 2009). Diethylnitrosamine (DEN) is a potent hepatocarcinogenic nitrosamine, present in cheddar cheese, cured and fried meals, alcoholic beverages, cosmetics, agricultural chemicals and pharmaceutical agents, ground water having high level of nitrate (Mahmoud and Abdul-Hamid, (2012). Carbon tetrachloride (CCl4) is classified as a possible human carcinogen based on inadequate evidence of carcinogenicity in humans but sufficient evidence in animals. However, there are major deficiencies in the available cancer studies. Animal studies suggested that the carcinogenicity of carbon tetrachloride is secondary to its hepatotoxic effects, indicating a possible threshold (Provincial,2010). Tomato products contains lycopene which is believed to be associated with decreased risk of chronic diseases, and its effects are suggested to be due to antioxidant effect of lycopene (Jamshidzadeh et al., 2008). The antioxidant properties of lycopene have been demonstrated both in vivo and in vitro (Wertz et al., 2004). There is also recent evidence suggests that lycopene acts as an anti-inflammatory agent (Kim et al., 2004). It has been demonstrated that lycopene can inhibit the expression of inflammatory cytokines and reverse the loss of antioxidant enzymes induced by inflammation caused by either injecting lipopolysaccharide or exposure to iron (Riso et al., 2006). Accordingly, the present study aimed to evaluate the beneficial effects and chemopreventive potential of lycopene on experimentally induced liver cancer in rats by diethylnitrosamine through evaluation of some serum liver biomarkers and molecular analysis of detoxification enzyme (CYP 2E1), tumor suppressor gene P53 and proinflammatory cytokines $\mathrm{TNF}-\alpha$ gene expression in hepatic tissues.

\section{Materials and methods}

\subsection{Experimental animals:}

Forty-five white male albino rats of 6- 8 weeks old and weighing 150 - $180 \mathrm{~g}$ housed in separated metal cages and kept at constant environmental and nutritional conditions throughout the period of experiment. The animals fed on constant ration and water was supplied ad- labium .

\subsection{Chemicals and antioxidant:}

All chemicals were of analytical grade and obtained from standard commercial suppliers. The antioxidant and chemicals used in the present study were:

2.2.1. Diethylnitrosamine (DEN) and Carbon tetrachloride (CCl4) were Purchased from SIGMA Chemical Co. (St. Louis, MO, USA) . Induction of Hepatocarcinogenesis:

Hepatocellular carcinoma was induced in rats by I. P injection of DEN in normal saline (200 $\mathrm{mg} / \mathrm{kg}$ b.wt), 2 weeks later rats received (2 $\mathrm{ml} / \mathrm{kg}$ b.wt) $\mathrm{CCl} 4$ orally at 1:1 dilution in corn oil as a promoter of carcinogenic effect. DEN and CCl4 administration were repeated once again after 1 month from the first DEN injection. (Hassan et al.,2014).

2.2.2. Lycopene was purchased from Aktin Chemicals, Inc. company (Nature connecting health), Chengdu, China .

Lycopene (100 $\mathrm{mg}$ ) was mixed in $2 \mathrm{ml}$ Tween-80\% at room temperature until a homogeneous paste was obtained. Physiologic saline at room temperature was added, drop wise and with vigorous stirring, to a final concentration of $20 \mathrm{mg}$ lycopene $/ \mathrm{ml}$ of suspension (Matos et al., 2000). Lycopene was given orally to rats at a dose level (20 $\mathrm{mg} / \mathrm{kg}$ b.wt/day) (Jiang et al., 2016).

\subsection{Experimental design:}

After acclimatization to the laboratory conditions, the animals were randomly divided into three groups (15 rats each) placed in individual cages and classified as follow : Group I: Control Normal group: 
Consisted of 15 male rats fed with ordinary diet only without any treatment during the entire experimental period.

Group II: DEN- induced hepatocarcinogenesis group:

Consisted of 15 male rats received DEN in normal saline $(200 \mathrm{mg} / \mathrm{kg}$ b.wt) by I.P injection, two weeks later rats received $(2 \mathrm{ml} /$ $\mathrm{kg}$ b.wt) $\mathrm{CCl} 4$ orally at 1:1 dilution in corn oil as a promoter of carcinogenic effect. DEN and $\mathrm{CCl} 4$ injections were repeated once again after 1 month from first DEN injection.

Group III: DEN + lycopene treated group: Consisted of 15 male rats received DEN in normal saline $(200 \mathrm{mg} / \mathrm{kg}$ b.wt $)$ by I.P injection, 2 weeks later rats received $(2 \mathrm{ml} / \mathrm{kg}$ b.wt) $\mathrm{CCl} 4$ orally at 1:1 dilution in corn oil as a promoter of carcinogenic effect. DEN and $\mathrm{CCl} 4$ administration were repeated once again after 1 month from first DEN injection then treated orally with lycopene dissolved in tween-80\% at a dose level $(20 \mathrm{mg} / \mathrm{kg}$ b.wt/day).

\subsection{Sampling:}

\subsubsection{Blood samples:}

Twenty-four hours fasting after the last dose of the drugs treatment administration, rats were anaesthetized under diethyl ether anesthesia. Blood samples were collected by ocular vein puncture in dry, clean tubes and allowed to clot for 30 minutes and serum was separated by centrifugation at 3000 r.p.m for 15 minute. Serum was taken by automatic pipettes and collected in dry sterile tubes, then kept in deep freeze at $-20{ }^{\circ} \mathrm{C}$ until use for subsequent biochemical analysis. All sera were analyzed for determination of the following parameters: AST, ALP, total bilirubin, Albumin, AFP .

\subsubsection{Liver tissue for molecular analysis}

Briefly, liver tissues were cut, weighed and minced into small pieces, about $0.5 \mathrm{~g}$ of liver tissues were collected from all animals groups, put in eppendorf tubes and were immediately kept in liquid nitrogen and stored at $-80^{\circ} \mathrm{C}$ till RNA extraction. The molecular analysis of the relative gene expression in liver tissues evaluated by reverse transcription polymerase chain reaction (RT-PCR) were: (TNF- $\alpha$, p53 and Cyp2E1 gene).

\subsection{Analysis:}

\subsubsection{Biochemical analysis:}

Serum ALT and ALP activities, total bilirubin, albumin and AFP concentrations were determined according to the method described by Schumann et al. (2002), ELAaser and EL-Merzabani, (1975), Young, (1997) and Doumas et al. (1971) and Engall, (1980), respectively.

\subsubsection{Molecular analysis:}

Total RNA was isolated from liver tissue of rats using RNeasy Mini Kit (Thermo Qiagen, \#74104) according to the manufacturer's protocol. Following determination of RNA concentration and purity by Quawell nanodrop Q5000 (USA), $5 \mathrm{mg}$ of total RNA from each sample was reverse transcribed using Quantiscript reverse transcriptase. The produced cDNA was used as a template to determine the relative expression of Tumor necrosis factor alpha (TNF- $\alpha)$, tumor suppressor (P53) and cytochrome P450 2E1 (Cyp2E1) genes using Step One Plus real time PCR system (Applied Biosystem, USA) and gene specific primers. The reference gene, $\beta$ actin, was used to calculate fold change in target genes expression. The thermal cycling conditions, melting curves temperatures, and calculation of relative expression was done. For the treated groups, assessment of $2-\Delta \Delta \mathrm{Ct}$ determined the fold change in gene expression relative to the control (Livak and Schmittgen, 2001).

\subsection{Statistical analysis:}

The results were expressed as mean $\pm \mathrm{SE}$ using SPSS software program version 16 (SPSS $\odot$ Inc., USA). The data were analyzed using one-way ANOVA to determine the statistical significance of differences among 
groups. Duncan's test was used for making a comparison among the groups for testing the inter-grouping homogeneity. Values were considered statistically significant when $\mathrm{p}<0.05$.

Forward and reverse primers sequence for real time PCR.

\begin{tabular}{|c|c|c|}
\hline Gene & $\begin{array}{r}\text { Forward primer } \\
\left(5--y^{-} 3\right)\end{array}$ & $\begin{array}{r}\text { Reverse primer } \\
\left(5-y^{-}-{ }^{-} 3\right)\end{array}$ \\
\hline TNF- $\alpha$ & GCATGATCCGCGACGTGGAA & AGATCCATGCCGTTGGCCAG \\
\hline $\mathrm{p} 53$ & ATGGCTTCCACCTGGGCTTC & TGACCCACAACTGCACAGGGC \\
\hline CYP2E1 & СTCCTCGTCATATCCATCTG & GCAGCCAATCAGAAATGTGG \\
\hline$\beta$-actin & AAGTCCCTCACССТCCCAAAAG & AAGCAATGCTGTCACCTTCCC \\
\hline
\end{tabular}

\section{RESULTS}

The obtained results demonstrated in table (1) revealed that, serum ALT and ALP activities, total bilirubin and AFP concentrations were significantly elevated and serum albumin level was significantly decreased in DEN induced liver cancer in rats when compared with the control normal group. Lycopene multiple

treatment to DEN-induced HCC significantly prevented these changes, resulting in a remarkable protection regarding the same parameters with the ability to restore the value of serum ALT, ALP, total bilirubin, albumin and AFP nearly to the average level of control group when compared with DEN-induced HCC group.

The obtained qPCR results presented in table (2) revealed a significant up-regulation of TNF- $\alpha$ gene expression level in liver tissue of DEN-induced liver cancer in rats. This expression was significantly downregulated after treatment with Lycopene. However, a significant downregulation of p53 and Cyp2E1 gene expression levels were observed in liver of DEN induced $\mathrm{HCC}$ in rats as compared to the normal control group. This expression was significantly upregulated following treatment by Lycopene when compared with DEN group.

Table1. Effect of Lycopene treatment on serum ALT and ALP activities, total bilirubin, Albumin and AFP concentrations in DEN-induced $\mathrm{HCC}$ in rats.

$\begin{array}{llllll}\text { Parameters } & \text { ALT }(\mathrm{U} / \mathrm{L}) & \text { ALP(U/L) } & \text { T. bilirubin(mg/dl) } & \text { Albumin }(\mathrm{g} / \mathrm{dl}) & \text { AFP }(\mathrm{ng} / \mathrm{dl})\end{array}$

\begin{tabular}{|c|c|c|c|c|c|}
\hline \multicolumn{6}{|l|}{ Exp. groups } \\
\hline $\begin{array}{l}\text { Group I: } \\
\text { Normal control }\end{array}$ & $190.00 \pm 11.55^{\mathrm{b}, \mathrm{c}}$ & $358.00 \pm 27.14^{\mathrm{b}}$ & $0.58 \pm 0.02^{\mathrm{b}}$ & $3.23 \pm 0.12^{\mathrm{a}}$ & $0.73 \pm 0.007^{\mathrm{c}}$ \\
\hline $\begin{array}{l}\text { Group П: } \\
\text { DEN }\end{array}$ & $365.00 \pm 14.43^{\mathrm{a}}$ & $490.00 \pm 11.55^{\mathrm{a}}$ & $1.75 \pm 0.03^{\mathrm{a}}$ & $1.80 \pm 0.17^{\mathrm{b}}$ & $4.90 \pm 0.47^{\mathrm{a}}$ \\
\hline $\begin{array}{l}\text { Group III: } \\
\text { DEN+lycopene }\end{array}$ & $231.33 \pm 0.88^{\mathrm{b}}$ & $416.67 \pm 14.53^{b}$ & $0.96 \pm 0.2^{\mathrm{b}}$ & $2.7 \pm 0.06^{\mathrm{b}}$ & $3.70 \pm 0.32^{\mathrm{b}}$ \\
\hline
\end{tabular}

Table 2. Effect of Lycopene treatment on liver tissue TNF- $\alpha$, P53 and Cyp2E1 gene expression level in DEN induced $\mathrm{HCC}$ in rats.

\begin{tabular}{|c|c|c|c|}
\hline $\begin{array}{l}\text { Parameters } \\
\text { Exp. groups }\end{array}$ & $\begin{array}{c}\text { TNF- } \alpha \\
\text { Fold change } \\
\text { mean } \pm \text { SEM }\end{array}$ & $\begin{array}{c}\text { p53 } \\
\text { Fold change mean } \pm \\
\text { SEM }\end{array}$ & $\begin{array}{c}\text { Cyp2E1 } \\
\text { Fold change mean } \pm \\
\text { SEM }\end{array}$ \\
\hline $\begin{array}{l}\text { Group I: } \\
\text { Normal control }\end{array}$ & $1.00^{d} \pm 0.09$ & $1.00^{a} \pm 0.06$ & $1.00^{a} \pm 0.06$ \\
\hline $\begin{array}{l}\text { Group } \Pi: \\
\text { DEN group }\end{array}$ & $7.52^{\mathrm{a}} \pm 0.36$ & $0.02^{d} \pm 0.01$ & $0.05^{c} \pm 0.005$ \\
\hline $\begin{array}{l}\text { Group III: } \\
\text { DEN +lycopene }\end{array}$ & $4.66^{b} \pm 0.21$ & $0.35^{c} \pm 0.02$ & $3.97^{\mathrm{a}} \pm 0.09$ \\
\hline
\end{tabular}


Mean values with different superscript letters in the same column are significantly different at $(\mathrm{P} \leq 0.05)$.

\section{DISCUSSION}

Hepatocellular carcinoma (HCC) is a primary malignancy of the liver and occurs predominantly in patients with underlying chronic liver disease and cirrhosis (Alison, 2005). $N$-Nitrosodiethylamine (DEN) causes a wide range of tumors in all animal species and such compounds are hazardous to human health. The formation of reactive oxygen species (ROS) is apparent during the metabolic biotransformation of DEN resulting in oxidative stress. Oxidative stress leads to carcinogenesis by several mechanisms including DNA, lipid and protein damage, change in intracellular signaling pathways and even changes in gene expression (Balamurugan and Karthikeyan, 2012). Also, DEN is a potent hepatic carcinogen agent (Mahmoud and Abdul-Hamid, 2012). On the other hand, Carbon tetrachloride (CCl4) produced hepatocellular adenomas and carcinomas in rats, mice and hamsters in oral studies and in rats and mice by inhalation exposure (Manibusan, 2010). DEN and CCl4 is hydroxylated principally by the ethanol inducible CYP2El (cytochrome P450 system) in liver (Verna et al., 1996; Weber et al., 2003).

The obtained results revealed that, serum ALT and ALP activities, total bilirubin and AFP concentrations were significantly elevated and serum albumin level was significantly decreased in DEN/CCl4 induced liver cancer in rats. $\mathrm{DEN}+\mathrm{CCl} 4$ administration induce extensive necrosis and inflammatory infiltration, clusters of hepatocytes, bile duct proliferation and marked atypia (Abd EL- Hamid et al., 2013) or caused hepatic damage by those two toxicants which reflects instability of liver cell metabolism that led to leakage of theses enzymes to circulation. (Hassan et al., 2014). Similarly, Hemieda et al. (2016) showed that treatment with DENA/CCl4 elevate the values of serum ALT, AST and ALP activities and total bilirubin level and markedly decreased serum total proteins and albumin concentrations. Also, Hashem et al. (2016) confirmed that administration of DEN/CCl4 significantly increased liver weight, relative liver weight, AST, ALT and ALP while, body weight, total protein, albumin and $\mathrm{A} / \mathrm{G}$ ratio were markedly decreased. Furthermore, Liver is the main site of DEN metabolism, the generation of ROS in the liver is recognized as an important contributor in DEN-induced damage (Faten et al., 2014). CCl4 is biotransformed by cytochrome P450 (CYP) enzyme system in the endoplasmic reticulum to produce trichloromethyl free radicals $(\mathrm{CCl} 3)^{\circ}$. Then $\mathrm{CCl} 3 \cdot$ leads to elicitation of lipid peroxidation (LPO) and destruction of $\mathrm{Ca}^{2+}$ homeostasis, resulting in cell death (Talib, 2012). Moreover, Borai et al. (2017) displayed that a significant elevation in serum AST, ALT and ALP enzymes activities were observed in DEN-treated group as compared to control normal rats indicating that DEN could induce a damaged effect on liver tissues. The elevation in enzymes activities is due to the rupture in the architecture of cell membrane and the leakage and liberation of enzymes into the serum as a result of carcinogenesis, necrosis and toxicity. Also, ALP indicates alteration in biliary flow. Therefore, during carcinogenesis, these enzymes could be used as biomarkers for HCC response to therapy according to (Tork et al.,2015). Furthermore, Vandenberghe, (1996) reported that hypoalbuminemia may result from liver disorders, which are accompanied by a reduction in albumin synthesis. Albumin is a key component of serum proteins. Also, liver toxicity resulted in decrease serum albumin level (Adams et al., 2005). The results of the present study are in agreement with this finding and demonstrate 
the decreased functional ability of $\mathrm{CCl} 4-$ injected rat livers (Saravanan et al.,2006).

Meanwhile, treatment with lycopene to DEN$\mathrm{CCl} 4$ induced $\mathrm{HCC}$ rats caused a significant decrease in serum ALT and ALP activities, and total bilirubin and increase in albumin level when compared with DEN/CCL4 induced HCC group. These results were agreement with Ebrahem et al. (2012) who showed that tomato extract (lycopene) supplementation after eight weeks of ethanol administration led to significant lowered in serum ALT and ALP activities. Lycopene is a bioactive compound of tomato exerting antioxidant and anti-inflammatory properties (Reifen et al., 2004). It has been demonstrated that lycopene can inhibit the expression of inflammatory cytokines and reverse the loss of antioxidant enzymes induced by inflammation (Riso et al., 2006). Also, Jamshidzadeh et al. (2008) reported that tomato supplementation ameliorates biochemical indices and oxidative parameters in induced liver injury.

Administration of DEN/CCl4 significantly elevated the serum AFP level when compared to normal rats. Similar data was reported by Borai et al. (2017) and Salama et al. (2017) who recognized that AFP concentration was significantly higher in the DEN-treated group as compared to control normal one. It was reported that in DEN induced hepatocarcinogens caused elevation in AFP level (which is widely used as tumor marker for diagnosis of HCC) associated with the increment in tumor growth and progression (Murugan et al., 2015). Similarity, Hashem et al. (2016) reported that a significant increase in AFP level was showen in $\mathrm{DEN}+\mathrm{CCl} 4$ group. The increase in serum AFP concentration has been used as a clinical marker in the diagnosis and monitoring of HCC (Tork et al., 2015). Moreover, Zaazaa et al. (2018) found that an increase in serum AFP level was observed in DEN-induced
$\mathrm{HCC}$ in rats when compared to control group. Additionally, alpha fetoprotein (AFP) is the most commonly used tumor markers for the diagnosis of hepatocellular carcinoma (HCC) which is a unique immune-modulatory glycoprotein, and normally made by the immature hepatocytes in the fetus (oncofetal). Detection of AFP during monitoring of liver cancer treatment is well accepted in patients with increased AFP level before therapy. It has been recognized that exposure of animals with DEN increases the circulating AFP level (Sadik et al. et al., 2008).

Treatment with lycopene to DEN/CCL4 induced $\mathrm{HCC}$ in rats caused a significant decrease in serum AFP level when compared with DEN/CCL4 non-treated group. The results approved by Bhatia et al. (2015) who investigated that, an elevated level of AFP observed in Nitrosodiethylamine Induced Hepatocellular Carcinoma in mice clearly indicated the onset of HCC in this group and suppression of AFP in Lycopene Enriched Tomato Extract treated mice revealed the anticancer potential of Lycopene that inhibits angiogenesis, and metastatic markers in earlystage n-nitrosodiethylamine induced hepatocellular carcinoma. Similarly, Das et al. (2016) stated that Lycopersicon esculentum significantly reduced the rise in AFP level when compared with DEN/PB group. This reduction in of AFP to near normal level may be due to inhibitory effect which confirms the chemo preventive property (Glory and Thiruvengadam.,2012).

The obtained qPCR results revealed significant elevation of TNF- $\alpha$ gene expression level in liver tissue of DEN/CCL4 induced $\mathrm{HCC}$ in rats as compared to the normal control group. Similarity, Kumar et al. (2016) found that TNF- $\alpha$ level significantly increased in DEN treated animals. Also, Habib et al. (2008) demonstrated that elevation in expression of TNF- $\alpha$ was 
observed in ethionine-induced hepatoma in rats. Moreover, Song et al. (2013) showed that DEN-induced HCC increased TNF- $\alpha$, which is pro-inflammatory cytokines produced by macrophages and it plays an important role under tumor conditions (Lutsiak et al., 2005). It has been reported that TNF- $\alpha$ is an essential factor in tumor promotion (Reuter et al., 2011). Exposure of liver tissue to certain hepatotoxicants induces the release of pro-inflammatory cytokines such as nitric oxide, TNF- $\alpha$, and transcription factors such as NF-kB by kupffer cells which can further aggravate the tumor progression by triggering of inflammatory cascade (Gupta et al.,2014). Moreover, Hamid et al. (2017) stated that $\mathrm{CCl} 4$ elevated proinflammatory cytokines TNF- $\alpha$, IL- 6, COX-2 and NFkB. An increased level of TNF- $\alpha$ was also shown to correlate with hepatic inflammation, necrosis, and hepatic failure (Budhu and Wang, 2006).

Treatment with lycopene to DEN/CCL4 induced $\mathrm{HCC}$ in rats caused a significant down-regulation in TNF- $\alpha$ gene expression and NF-kB gene expression when compared with DEN/CCL4 non-treated group. These results are agreement with Bhatia et al. (2015) who reported that, lycopene administration to DEN treated mice modulate the serum levels of these cytokines (TNF- $\alpha$, IL-1 $\beta$ and IL-6) by inhibiting their production and induction of apoptosis thus showing its antiinflammatory effect. Some literature also supported the amelioration of these inflammatory markers upon administration of lycopene (Riso et al., 2006; Feng et al., 2010). Also, Bahcecioglu et al. (2010) showed that TNF- $\alpha$ level was reduced after lycopene treatment, indicating the anti-inflammatory effect of lycopene.

The obtained qPCR results revealed significant down regulation of p53gene expression level in liver tissue of DEN/CCL4 induced $\mathrm{HCC}$ in rats as compared to the normal control group. Similarity, Loyden et al. (2017) demonstrated that a significant reduction in p53 gene expression was observed in DEN administration group. The p53 protein acts as a central response to cellular stress or DNA damage by inducing cell cycle arrest, apoptosis, senescence, and other tumor-suppressive actions (Bisteau et al.,2014). Moreover, Khan et al. (2016) stated that decrease in p53 expression induced with $\mathrm{CCl} 4$, which explained thatCCl4 acts as a tumor promoter through increasing the intracellular concentration of ROS necrosis/regeneration and cell proliferation and/or may be due to mutation of p53 (Farazi et al., 2006). This notion supported by findings that p53 is the most commonly mutated tumor suppressor gene and a lacking p53 function is related to an enhanced risk of carcinogenesis (Donehower et al.,1992).

Treatment with lycopene to DEN/CCL4 induced $\mathrm{HCC}$ rats caused a significant upregulation in p53 gene expression when compared with DEN/CCL4 induced HCC group. Some medicinal phytochemical plants induced upregulation in p53 gene expression. Similarity, Khan et al. (2012) found that rutin increase in p53 and CYP 2E1 expression after reduced by $\mathrm{CCl} 4$ induced hepatotoxicity. Also, George et al. (2011) reported that increased expression in total p53 was observed in skin tissue/tumor treated with resveratrol and BTP. Moreover, Clark et al. (2015) suggested that anticancer activity of capsaicin and 3,3'-diindolylmethane in human colorectal cancer by activation of transcriptional activity of nuclear factor kappa $\beta$ and p53.

The obtained results revealed significant down-regulation of Cyp2E1 gene expression level in liver tissue of DEN/CCL4 induced HCC in rats. Similarity, Zhang et al. (2013) found that DEN treatment resulted in significant decrease in the activities of CYP2E1, CYP1A2. It has been well 
documented that DEN-induced hepatocarcinogenesis requires metabolic activation by some forms of CYP450, especially CYP2E1. Furthermore, Khan et al. (2016) displayed that significant decrease in CYP 2E1 expression in CCl4-induced hepatotoxicity, who confirmed that reactive oxygen species formed during the biotransformation process of $\mathrm{CCl} 4$ are more reactive and toxic than the parental compound. Biotransformation of $\mathrm{CCl} 4$ occurs in the endoplasmic reticulum and the isoenzyme implicated in this process is CYP2E1 (Knockaert et al., 2012).

Treatment with lycopene to DEN-CCl4 induced HCC rats caused a significant upregulation in Cyp2E1 gene expression when compared with DEN-CCl4 induced HCC group. Similarity, other medicinal phytochemical plants induced upregulation in Cyp2E1 gene expression like Khan et al. (2012) who showed that the active free radical/intermediate of $\mathrm{CCl}_{4}$ caused a reduction in CYP2E1, which was markedly restored by rutin treatment. Also, Zhanget al. (2013) reported that garlic oil elevated Cyp2E1 level after reduced by DEN induced hepatocarciongenisis in rats. Furthermore, Shirakami et al. (2011) demonstrated that Lecithin: retinol acyltransferase (LRAT) KO mice exhibited suppressed DEN-induced liver tumour development by decreased levels of CYP enzymes needed for the bio-activation of DEN resulting in less DNA-adduct formation and cancer initiation. Moreover, Weerachayaphorn et al. (2010) displayed that, curcuma comosa increased hepatic CYP2E1 after reduced by $\mathrm{CCl} 4$ treatment.

\section{Conclusion}

It could be concluded that, lycopene was able to mitigate liver tissue damage induced by DEN through increasing of Cyp2E1 and P53 and decreasing TNF- $\alpha$ gene expression level as well as ameliorate all serum liver function parameters. These findings suggested, the potential efficacy of lycopene as an additional chemo preventive agent in treatment of hepatocellular carcionoma by modulating the apoptosis, anti-inflammatory and detoxification effects.

\section{REFERENCES}

Abd El-Hamid, N.M.; Abd El-Ghany, M.I.; Nazmy, M.H. and Amgad, S.W. 2013. Can methanolic extract of Nigella sativa seed affect glyco-regulatory enzymes in experimental hepatocellular carcinoma? Enviroment. Health Prev. Med. 18:49-56.

Adams, L.A.; Lymp, J.F.; St Sauver, J.; Sanderson, S.O.; Lindor, K.D.; Feldstein, A. and Angulo, P. 2005.The natural history of nonalcoholic fatty liver disease: apopulation-based cohort study. Gastroenterology.; 129(1):113-21.

Bahcecioglu, I.H.; Kuzu, N.; Metin, K.; Ozercan, I.H.; Ust"undag, B.; Sahin, K. and Kucuk, O. 2010. Lycopene Prevents Development of Steatohepatitis in Experimental Nonalcoholic Steatohepatitis Model Induced by High-Fat Diet. Vet Med Int..

Bhatia, N.; Gupta, P.; Singh, B. and Koul, A.2015. Lycopene Enriched Tomato Extract Inhibits Hypoxia, Angiogenesis, and Metastatic Markers in early-Stage N-Nitrosodiethylamine Induced Hepatocellular Carcinoma. Nutr Cancer.;67(8):1268-75.

Budhu, A., Wang, X. W. 2006. The role of cytokines in hepatocellular carcinoma. J Leukoc Biol.; 80:1197-1213.

Bisteau, X.; Caldez, M.J. and Kaldis, P. 2014. The complex relationship between liver cancer and the cell cycle: 
a story of multiple regulations. Cancers; 6(1): 79-111.

Borai, I.H.; Ghanem, H.M.; Ali, M.M.; AbdelHalim, A.H.; Hegazi, A. E.A.; and Mousa, F.M. 2017.Chemopreventive Effect of Momordicacharantia Extract Against Chemically Induced Hepatocellular Carcinoma in Experimental Animals. RJPBCS 8(2) Page No. 529 ISSN: 0975-8585.

Balamurugan, K., Karthikeyan, J. 2012. Evaluation of Luteolin in the Prevention of N-nitrosodiethylamineinduced Hepatocellular Carcinoma Using Animal Model System. Indian J Clin Biochem.; 27: 157-163.

Clark, R.; Lee, J. and Lee, S.H. 2015. Synergistic anticancer activity of capsaicin and 3,3'-diindolylmethane in human colorectal cancer. Agric. Food Chem., 63, 4297.

Das, B.K.; Koti, B.C. and Gadad, P.C. 2016. Role of Lycopersicon esculentum in diethylnitrosamine-induced and phenobarbital-promoted hepatocellular carcinoma. Indian J Health Sci Biomed Res; 9:147-52.

Donehower, L.A.; Harvey, M.; Slagle, B.L.; McAr-thur, M.J.; Montgomery, C.A.Jr.; Butel, J.S. and Bradley, A. 1992. Mice deficient for p53 are developmentally normal but susceptible to spontaneous tumours. Nature 356:215-221.

Dumas, B. T.; Watson, W. A. and Biggs, H.G.1971. Albumin standards and the measurement of serum albumin with bromcresol green. 1971. ClinChimActa. Feb 3;258(1):21-30.

Ebrahem, E.E.; Youssef, E.M.I.; Bayoumy, E.S. And Samaha, S. R. 2012. Natural antioxidant effects on ethanol induced liver injury in albino rats. AAMJ, Vol. 10, N. 3, Sep, Suppl-1.

EL-Aaser, A. A. and EL-Merzabani, M. M. 1975. Simultaneous determination of 5'-nucleotidase and alkaline activities in serum. Z. Klin. Chem. Klin. Biochem., 13,453.

Engall, E. 1980. Methods in Enzymology, Volume 70, Van Vunakis, $H$. and Langone, J. J. (eds.), Academic Press, New York, 419-492.

Farazi, P.A.; Zeisberg, M.; Glickman, J.; Zhang, Y.; Kalluri, R. and DePinh, R.A. 2006. Chronic bile duct injury associated with fibrotic matrix microenvironment provokes cholangiocarcinoma in p53-deficient mice. Nutri.;6:6622-6627.

Faten, Z.M.; Sultan, S.A. and Al-shimaa, M.A. 2014. Chemopreventive and therapeutic effect of capsaicin against diethylnitosamine induced liver injury and hepatocellular carcinoma in rats.int. J. Biol. Pharmaceuit. Res. 5(8): 630-642.

Feng, D.; Ling, W.A. and Duan, R.D. 2010. Lycopene suppresses LPS-induced NO and IL- 6 production by inhibiting the activation of ERK, p38MAPK, and NF-kB in macrophages. Inflamm Res; 59:115-21.

George, J.; Singh, M.; Srivastava, A.K.; Bhui, K.; Roy, P.; Chaturvedi, P.K. and Shukla, Y. 2011. Resveratrol and black tea polyphenol combination synergistically suppress mouse skin tumors growth by inhibition of activated MAPKs and p53. PLoS One, 6, e23395.

Glory, M.D. and Thiruvengadam, D. 2012. Potential chemopreventive role of 
chrysin against N-nitrodiethylamineinduced hepatocellular carcinoma in rats. Biomed Prev Nutr; 2:106-12.

Gold, S.L.; Ames, N.B. and Slone, H.T. 2002. Misconceptions about the causes of cancer. D. Paustenbach, ed., 14151460.

Gupta, S.C.; Tyagi, A.K.; Deshmukh-Taskar, P.; Hinojosa, $\quad$ M.; Prasad, S. and Aggarwal, B. 2014. Downregulation of tumor necrosis factor and other proinflammatory biomarkers by polyphenols. Arch. Biochem. Biophy.559, 91-99.

Habib, S.H.M.; Makpol, S.; Hamid, N.A.A.; Das, S.; Ngah, W.Z.W. and Yusof, Y.A.M. 2008. Ginger extract has anticancer and anti-inflammatory effects on ethionine-induced hepatoma rats. Clinics; 63:807-813.

Hamid, M.; Liu, D.; Abdulrahim, Y.; Liu, Y.; Qian, G.; Khan, A.; Gan, F. and Huang, K. 2017. Amelioration of CCl4-induced liver injury in rats by selenizing Astragalus polysaccharides: Role of proinflammatory cytokines, oxidative stress and hepatic stellate cells.; 114:202-211.

Hashem, S.; Taha, N.M.; Mandour, A.A.; Lebda, M.A.; Balbaa, M.E.; and ElMorshedy, A.S. 2016. Hepatoprotective Effect of Silymarin and Propolis in Chemically Induced Chronic Liver Injury in Rats: Alexandria J Vet Sci, Apr. 49 (1): 35-43.

Hassan, S.K.; Mousa, A.M.; Eshak, M.G.; Farrag, A.R.H. and Badawi, A.F.M. 2014. Therapeutic and chemopreventive effect of nanocurcumin against diethyl nitrosamine induced hepatocellular carcinoma in rats. Int. J. Pharmcol. Pharmceuit. Sci. 6(3): 54-62.

Hemieda, F.A.E.; Serag, H.M.; El-Baz, E. and Ramadan, S.M.E. 2016. Therapeutic efficacy oflicorice and/or cisplatin against diethylnitrosamine and carbon tetrachloride-induced hepatocellular carcinoma in rats. J Am Sci;12(1):1019.

Jamshidzadeh, A.; Baghban, M.; Azarpira, N.; Bardbori, A. M. and Niknahad, $\mathrm{H}$. 2008. Effects of tomato extract on oxidative stress induced toxicity in different organs of rats. Food Chem. Toxicol., 46 (12). 3612-3615.

Jiang, Q.; Han, Y.; Gao, H.; Tian, R.; Li, P. and Wang, C. 2016. Ursolic acid induced anti-proliferation effects in rat primary vascular smooth muscle cells is associated with inhibition of microRNA-21 and subsequent PTEN/PI3K. Eur J Pharmacol. ;781:6975.

Khan, R.A.; Khan, M.R. and Sahreen, S. 2012. CCl4-induced hepatotoxicity: protective effect of rutin on $\mathrm{p} 53$, CYP2E1 and the antioxidative status in rat. BMC Complementary and Alternative Medicine12:178.

Khan, R.A.; Khan, M.R.; Sahreen, S. and Alkreathy, H.M. 2016. Effect of Launaea procumbens extract on oxidative marker, p53, and CYP 2E1: a randomized control study. Food \& Nutrition Research 03 Mar, 60:29790.

Kim, G.Y.; Kim, J.H.; Ahn, S.C.; Lee, H.J.; Moon, D.O.; Lee, C.M. and Park, Y.M. 2004. Lycopene suppresses the lipopolysaccharide-induced phenotypic and functional maturation of murine dendritic cells through inhibition of 
mitogen-activated protein kinases and nuclear factor-kappa B. Immunology, 113: 203-211.

Knockaert, L.; Berson, A.; Ribault, C.; Prost, P.E.; Fautrel, A.; Pajaud, J.; Lepage, S.; Lucas-Clerc, C.; Bégué, J.M.; Fromenty, B. and Robin, M. A. 2011. Carbon tetrachloride-mediated lipid peroxidation induces early mitochondrial alterations in mouse liver. Lab Invest.Mar;92(3):396-410.

Kumar, R.S.; Kumar, S.V.; Balasubramanian, R; Narayanaperumal, P. and Dharmasivam, M. 2016. Chemopreventive effect of Indigo feralinnaei extract against diethylnitrosamine induced hepatocarcinogenesis in rats. Journal of Applied Pharmaceutical Science 6 (11); 199-209.

Kung, C.J.; Curri, S.I.; Forbes, J.S.; James, A. and Ross, A.J. 2010. Liver development, regeneration, and carcinogenesis. Journal of biomedicine and biotechnology., 6 (10):1-8.

Livak, K.J. and Schmittgen, T.D. 2001. Analysis of relative gene expression data using real-time quantitative PCR and the $2(-\Delta \Delta \mathrm{Ct})$ method. Methods.; 25:402-408.

Loyden, G. V., Martínez, L.P.; Gómez, S.V.; Carreón, J.I.P. and de Sánchez, V.C. 2017. Cancer chemoprevention by an adenosine derivative in a model of cirrhosis-hepatocellular carcinoma induced by diethylnitrosamine in rats. Tumour Biol. Feb; 39(2):1010428317691190.

Lutsiak, M.E.; Semnani, R.T.; De Pascalis, R.; Kashmiri, S.V.; Schlom, J. and Sabzevari, H. 2005. Inhibition of
$\mathrm{CD} 4+25+\mathrm{T}$ regulatory cell function implicated in enhanced immune response by low dose cyclophosphamide. Blood 105: 2862-2868.

Mahmoud, M.S. and Abdul-Hamid, M. 2012. Green tea extract ameliorates Liver and pituitary gland toxicity induced by diethylnitrosamine in male rats. $\mathrm{J}$ Am Sci., 8(3): 58-71.

Manibusan, M.; Jinot, J.; Kopylev, L.; White, P.; Schlosser, P.and Park, T. 2010. Toxicological review of carbontetrachloride. EPA., (56-23-5):1473.

Matos, H.R.; Di Mascio, P. and Medeiros, M.H. 2000. Protective effect of lycopene on lipid peroxidation and oxidative DNA damage in cell culture. Arch Biochem Biophys; 383: 56-59.

Mukherjee, B.; Ghos, K.M. and Chowdhury, H.M. 2009. Chemically induced hepatocellular carcinoma and stages of development with biochemical and genetic modulation: a Special reference to insulin-like growth factor II and Raf gene signaling. ICMR., (58):201-219.

Murugan, S.; Ameesh, M.N.; Shilpa, S.; Vishal, B. 2015. Study on the Anticarcinogenic Efficacy of Withaferin-A in DEN Induced Hepatocellular Carcinoma: Morphology and Histopathology. IJHSR. 273 Vol.5; Issue: 9.

Provincial, F. 2010. Guidelines for canadian drinking water quality: guideline technical document - carbon tetrachloride. ISBN.,2-5.

Reifen, R.; Nissenkorn, A.; Matas, Z. and Bujanover, Y. 2004. 5-ASA and lycopene decrease the oxidative stress and inflammation induced by iron in 
rats with colitis. J. Gastroenterol., 39:514-519.

Reuter, S.; Gupta, S.; Park, B.; Goel, A. and Aggarwal, B. B. 2011. Epigenetic changes induced by curcumin and other natural compounds. Genes Nutr, 6, 93-108.

Riso, P.; Visioli, F.; Grande, S.; Guarnieri, S.; Gardana, C.; Simonetti, P. and Porrini, M. 2006. Effect of a tomato-based drink on markers of inflammation, immunomodulation, and oxidative stress. J. Agric Food Chem., 54:25632566.

Sadik, N.A.H.; EL-Maraghy, S.A. and Ismail, M. F. 2008. Diethylnitrosamineinduced hepatocarcinogenesis in rats: possible chemoprevention by blueberries: Afr. J. Biochem. Res. Vol.2 (3), pp. 081-087, March.

Saravanan, R.; Viswanathan, P. and Pugalendi, K.V. 2006. Protective effect of ursolic acid on ethanol-mediated experimental liver damage in rats. Life Sci.;78(7):713-8.

Satir, A.A. 2007. An update on the pathogenesis and pathology of hepatocellular carcinoma. Bahrain Medical Bulletin., 29(2):1-7.

Schumann, G.; Bonora, R.; Ceriotti, F.; Férard, G.; Ferrero, C.A.; Franck, P.F.H.; Gella, F.J.; Hoelzel, W.; Jørgensen, P.J.; Kanno, T.;Kessner, A.;Klauke, R.; Kristiansen, N. 2002. IFCC primary reference procedures for the measurement of catalytic activity concentrations of enzymes at $37{ }^{\circ} \mathrm{C}$ : Part 5. Reference procedure for the measurement of catalytic concentration of aspartate-aminotransferase. Clin. Chem. Lab Med.; 40:725-733.
Shirakami, Y.; Gottesman, M. E. and Blaner, W.S. 2012. Diethylnitrosamine-induced hepatocarcinogenesis is suppressed in lecithin: retinolacyltransferasedeficient mice primarily through retinoid actions immediately after carcinogen administration. Carcinogenesis; 33(2), 268-274.

Song, Y.; Jin, S.J.; Cui, L.H.; Ji, X.J. and Yang. 2013. Immunomodulatory Effect of Stichopus japonicus acid Mucopolysaccharide on experimental hepatocellular carcinoma in rats. Molecule. 18(4):7179-7193.

Tork, O.M.; Khaleel, E.F. and Abdelmaqsoud, O.M. 2015. Altered Cell to Cell Communication, Autophagy and Mitochondrial Dysfunction in a Model of Hepatocellular Carcinoma: Potential Protective Effects of Curcumin and Stem Cell Therapy. APJCP.16.18.8271.

Verna, L.; Whysner, J. and Williams, G.M. $1996 . \quad$ N-nitrosodiethylamine mechanistic data and risk assessment: bioactivation, DNA-adduct formation, mutagenicity, and tumor initiation. PharmacolTher; 71: 57-81.

Weber, L.W.; Boll, M.and Stampfl, A. 2003. Hepatotoxicity and mechanism of action of haloalkanes: Carbon tetrachloride as a toxicological model. Crit. Rev. Toxicol., 33, 105-136.

Weerachayaphorn, J.; Chuncharunee, A.; Jariyawat, S.; Lewchalermwong, B.; Amonpatumrat, S.; Suksamrarn, A. and Piyachaturawat, P. 2010. Protection of centrilobular necrosis by Curcuma comosa Roxb. in carbon tetrachlorideinduced mice liver injury. $\mathrm{J}$ Ethnopharmacol. 27; 129 (2): 254-60. 
Wertz, K.; Siler, U. and Goralczyk, R. 2004. Lycopene:modes of action to promote prostate health. Arch. Biochem. Biophysi., 430: 127-134.

Young D.S. 1997. Effects of Preanalytical Variables on Clinical Laboratory tests, 2nd ed. Washington, DC: AACC Press; $3-85$.

Zaazaa, A.M.; Lokman, M.S.; Shalby, A.B.; Ahmed, H.H. and El-Toumy, S.A. 2018. Ellagic Acid Holds Promise Against Hepatocellular Carcinoma in an Experimental Model: Mechanisms of Action. APJCP. 19.2.387.

Zhang, C.L.; Zeng, T.; Zhao, X.L. and Xie, K.Q. 2013. Garlic Oil Attenuated Nitrosodiethylamine-Induced Hepatocarcinogenesis by Modulating the Metabolic Activation and Detoxification Enzymes. Int J Biol Sci; 9(3):237-245. 